\title{
TEMPO PASSADO: CULTURA DA MEMÓRIA E GUINADA SUBJETIVA: \\ UM CONTRAPONTO AO BOOM DA MEMÓRIA NOS ESTUDOS HISTÓRICOS
}

\author{
Fernando C. Boppré \\ Mestrado do PPGH/UFSC \\ fernando.boppre@gmail.com
}

SARLO, Beatriz. Tempo passado: cultura da memória e guinada subjetiva. São Paulo:Companhia das Letras, 2007.

Nesta obra, Beatriz Sarlo procede a uma verdadeira devassa sobre os usos (e os abusos) da memória tanto nos estudos acadêmicos quanto na esfera jurídica, política e social. De uma parte, depara-se com o recente sucesso dos chamados livros 'não-ficcionais' no mercado editorial que produz uma avalanche de discursos enunciados em primeira pessoa: histórias de vida, autobiografias, entrevistas, biografias, memórias, entre outros. De outra parte, a autora constata que, em boa medida, as próprias ciências humanas também passaram a se dedicar e a incorporar os testemunhos pessoais em suas pesquisas.

Jay Winter, em balanço sobre aquilo que considera ser o boom da memória, reflete que o tema da memória, definido de várias maneiras, tornou-se “(...) o conceito central organizador dos estudos em história, uma posição antes ocupada por noções de classe, raça e gênero". . De outra parte, Benito Bisso Schmidt constata que termos como “(...) memória coletiva, enquadramentos, lugares da memória, esquecimento e testemunha já se tornaram lugares-comuns" ${ }^{2}$, muitas vezes associados aos nomes de Maurice Halbwachs, Michel Pollak, Paul Ricoeur e Pierre Nora. Sobre este último, vale destacar a importância para a história cultural dos livros que lançou na França entre 1984 e 1992, sob o título de Les lieux de mémoire, um verdadeiro inventário acerca da memória no contexto francês que culminou num estrondoso sucesso editorial.

Beatriz Sarlo, por sua vez, avalia que junto a esta demanda por este tipo de narrativas surgiram “(...) novas exigências e métodos que tendem à escuta sistemática dos 'discursos de memória': diários, cartas, conselhos, orações”’3. $\mathrm{O}$ entendimento acerca do passado terai se deslocado para aquilo que a literatura, desde o século XIX, experimentou como a primeira pessoa do singular. A chamada 'guinada subjetiva' seria, portanto, um ponto de inflexão na teoria e metodologia das ciências humanas: 
Tomando-se em conjunto essas inovações, a atual tendência acadêmica e do mercado de bens simbólicos que se propõe a reconstituir a textura da vida e a verdade abrigadas na rememoração da experiência, a revalorização da primeira pessoa como ponto de vista, a reivindicação de uma dimensão subjetiva, que hoje se expande sobre os estudos do passado e os estudos culturais do presente, não são surpreendentes. São passos de um programa que torna explícito, porque há condições ideológicas que o sustentam. Contemporânea do que se chamou nos anos 1970 e 1980 de 'guinada lingüística' ou muitas vezes acompanhado-a como sua sombra, impôs a guinada subjetiva ${ }^{4}$.

A partir da crítica encetada pela autora torna-se possível constatar os efeitos de uma leitura apressada das idéias de Charles Baudelaire sobre a modernidade e que culminaram numa espécie de ode ao instante, ao fugidio. A contradição assinalada por Sarlo é que no mesmo gesto em que a pós-modernidade reivindica as ditas "operações de apagamento" ou mesmo a dissolução do passado, procedese, no entanto, com uma verdadeira museificação das cidades e das práticas culturais. Assiste-se às décadas “(...) da heritage, do passado-espetáculo, das aldeias Potemkin e dos theme-parks históricos; daquilo que Ralph Samuel chamou de "mania preservacionista" "É É desta forma que as operações tanto com a história quanto com a memória participam do mercado simbólico do capitalismo tardio. Charles Maier definiu com sobriedade esta situação: "As sociedades ocidentais estão vivendo uma era de auto-arqueologização"6.

A posição tomada por Beatriz Sarlo frente a esta perspectiva, contudo, está mais para a reticência do que para a exclamação. Avalia que "(...) não se deve basear na memória uma epistemologia ingênua” e que, portanto, “(...) não há equivalência entre o direito de lembrar e a afirmação de uma verdade da lembrança"7. A crítica incide num certo regime de verdade, presidido - no caso europeu após o Holocausto e no latino-americano após as ditaduras militares - pelos testemunhos em primeira pessoa. É neste contexto que se reforçou a ambigüidade existente entre a memória e história: ambas passaram a reivindicar o passado. De um lado, a memória se julgaria capaz de retomar o pretérito a partir de lembranças e subjetividades, relacionando-se com a literatura, as artes e os estudos culturais. De outro, a história se apresentaria estruturada como disciplina acadêmica, com teorias e metodologias próprias, supostamente mais confiáveis para tal fim. Ainda assim, inegavelmente, a história se aproximou das questões provindas da memória. A história oral, por exemplo, que outrora participava do jornalismo e, quando muito, da etnografia, tornou-se disciplina acadêmica corrente, abarcando, com isso, os relatos em primeira pessoa no seio do ofício do historiador: "Nas últimas décadas, a história se aproximou da memória e aprendeu a interrogá-la; a expansão das 'histórias orais' e das micro-histórias é suficiente para provar que 
esse tipo de testemunho obteve uma acolhida tanto acadêmica como midiática"s. Além disso, incorporou-se ao repertório de leituras do historiador boa parte do pensamento de autores como Walter Benjamin, Jorge Luis Borges e Gilles Deleuze (este último que trouxe, num mesmo movimento, as idéias de Henri Bergson e o procedimento memorialístico de Marcel Proust). Todos estes autores, ainda que não tenham escrito nenhum livro onde formalizavam abertamente uma teoria da memória (exceto Bergson), destacaram-se nos termos de uma poética e de uma filosofia onde a memória ocupava uma posição central e cognitiva.

O grande problema da argumentação de Sarlo, no entanto, é que após uma crítica acirrada aos dispositivos da memória e a sua relação com a história, ela não consegue oferecer outra via razoável para o problema. Quando tenta fazêlo, no quarto capítulo intitulado "Experiência e argumentação", não sustenta suas idéias de maneira precisa. É a partir do livro de Pilar Calviero", torturada pelo regime militar argentino, que Sarlo vislumbra um novo paradigma para a relação entre a dimensão testemunhal e a história. $\mathrm{O}$ que haveria de singular na narrativa de Calviero seria o fato dela prescindir de seus sofrimentos, de manter aquilo que chama de "distância exata", uma capacidade de escutar "cientificamente", de fazer a teoria iluminar a experiência e não o contrário. Ou seja, Pilar Calviero não se utiliza de maneira voluntária de suas experiências pessoais no cárcere para legitimar sua narrativa; não se apresenta como testemunha, mas sim como analista do relato de terceiros (supostamente mais capacitada para tal função posto lançar mão de "teorias científicas"). Em última instância, Sarlo executa um estranho passo: ao criticar a memória, acaba deslegitimando o discurso daqueles que não estão familiarizados às teorias e às ciências, fazendo retornar para a academia o direito à verdade.

De outra parte, no entanto, a autora consegue realizar uma crítica oportuna a uma espécie de consenso existente nas discussões sobre a narrativa na contemporaneidade. A partir da obra de Walter Benjamin surgiu a idéia de que a narração estaria morta na contemporaneidade (o romance literário seria sua massa falida). Segundo o autor, a arte de narrar estaria em vias de extinção, sendo “(...) cada vez mais raras as pessoas que sabem narrar devidamente" ${ }^{10}$. Todavia, existe aí uma questão anterior: a experiência se preserva ou se dissolve na ação de narrar? "Não há testemunho sem experiência, mas tampouco há experiência sem narração: a linguagem liberta o aspecto mudo da experiência, redime-a de seu imediatismo ou de seu esquecimento e a transforma no comunicável, isto é no comum"11. Ou seja, a narração teria a capacidade de criar uma nova temporalidade para a experiência. Eis que diante de situações limites, entretanto, como as grandes guerras mundiais, decretou-se o fim da narrativa posto que a dimensão de experimentar o mundo se tornou, sobretudo, trágica e impotente.

O apogeu do testemunho é, em si mesmo, uma refutação daquilo que, nas primeiras décadas do século $\mathrm{XX}$, alguns 
consideraram seu fim definitivo. Walter Benjamin, diante das conseqüências da Primeira Guerra Mundial, expôs o esgotamento do relato devido ao esgotamento da experiência que lhe dava origem. Das trincheiras ou das frentes de batalha da guerra, ele afirmou, os homens voltaram emudecidos. É inegável que Benjamin se equivocava quanto à escassez de testemunhos, justamente porque 'a guerra de 1914-8 marca o começo do testemunho de massas' ${ }^{12}$.

Haveria após a guerra, segundo Walter Benjamin (e também segundo Giorgio Agamben cuja crítica foi realizada por Carlo Ginzburg ${ }^{13}$ ), a falta do relato do vivido e também da compreensão dessa experiência brutal. Sarlo sublinha o tom melancólico sobre o fim da narração que acompanha a escrita de Benjamin. Dom Quixote seria o signo irônico desse desencanto já que mesmo antes do choque que as guerras e as técnicas modernas ocasionariam, haveria um outro choque, desta vez provocado pelo "(...) surgimento do romance, que tomou o lugar das "formas artesanais' de transmissão" 14 . Sarlo questiona o pressuposto utópico destas considerações do autor de Passagens: ele admitiria um momento de plenitude dos sentidos, onde aquele que diz e aquele que ouve se entendem com assombro e sem distância: "Se seguimos Benjamin, acaba sendo contraditório em termos teóricos e equivocado em termos críticos afirmar a possibilidade do relato da experiência na modernidade" 15 . A filosofia da história proposta por Benjamin, prossegue Sarlo em sua crítica, seria portanto:

(...) uma reivindicação da memória como instância reconstituidora do passado. Os chamados 'fatos' da história são um 'mito epistemológico' que reifica e anula sua possível verdade, encadeando-os num relato dirigido por alguma teleologia. No rastro de Nietzsche, Benjamin denuncia o causalismo; no rastro de Bergson, reivindica a qualidade psíquica e temporal dos fatos da memória. O historiador, ao seguir essa afirmação em todas as suas conseqüências, não reconstitui os fatos do passado (isso equivaleria a se submeter a uma filosofia da história reificante e positivista), mas os 'relembra', dando-lhes assim seu caráter de passado presente, com respeito ao qual sempre há uma dívida não paga ${ }^{16}$.

A idéia de uma "retórica testemunhal" é o eixo central do terceiro capítulo. No contexto do fim das ditaduras latino-americanas, a lembrança tornou-se fonte para a restauração de laços sociais e comunitários. Neste mesmo movimento, contudo, alcançaram uma outra esfera: a jurídica. As recordações de parentes, amigos e conhecidos das vítimas tornaram-se prova jurídica para a condenação dos réus. Porém, a questão colocada por Sarlo é que ninguém, fora da esfera do judiciário, pensou em submetê-las a uma crítica metodológica: a qual regime de 
verdade responderia o testemunho em primeira pessoa? A confiança depositada jurídica e socialmente nestas lembranças foi necessária para a instalação de regimes democráticos e para a reparação das perdas. No entanto, outras narrativas, provindas de narradores anteriores ao período da ditadura, continuam sendo contestadas. Há um princípio de legitimidade irrestrita a estes testemunhos pósditadura que deve, contudo, ser questionado: "Só uma confiança ingênua na primeira pessoa e na lembrança do vivido pretenderia estabelecer uma ordem presidida pelo testemunhal" ${ }^{\prime 17}$.

Um outro ponto abordado no estudo é a questão da anacronia posto que a “(...) memória é sempre anacrônica: 'um revelador do presente', [conforme] escreveu Halbwachs" ${ }^{18}$. Para tanto, Sarlo recorre novamente aos escritos benjaminianos onde a anacronia encontra uma dimensão ética:

Essa discordância dos tempos é inevitável nas narrações testemunhais. A disciplina histórica também é perseguida pelo anacronismo, e um de seus problemas é justamente reconhecêlo e traçar seus limites. Todo ato de discorrer sobre o passado tem uma dimensão anacrônica; quando Benjamin se inclina por uma história que liberte o passado de sua reificação, redimindo-o num ato presente de memória, no impulso messiânico pelo qual o presente se responsabilizaria por uma dívida de sofrimento com o passado, ou seja, no momento em que a história pensa em construir uma paisagem do passado diferente da que percorre, com espanto, o anjo de Klee, ele está indicando não só que o presente opera sobre a construção do passado, mas que também é seu dever fazê-lo. ${ }^{19}$

A autora avalia que o núcleo do testemunho é a memória ao passo que o mesmo não funciona para a história. No testemunho, o anacronismo seria mais inevitável do que em outros gêneros de história. Georges Didi-Huberman, na esteira de Jacques Rancière, elaborou um pensamento sobre o tempo na história, chegando mesmo a elaborar uma espécie de 'epistemologia do anacronismo' que apareceria na dobra entre a imagem e a história. No livro Ante el tiempo ${ }^{20}$, defende a memória em detrimento à história. A memória seria uma organização impura, uma montagem 'não-histórica' do tempo. Estar-se-ia mais próximo, portanto, não de uma ciência, mas sim de uma poética. Os fatos do passado seriam reunidos em uma assemblage de anacronismos sutis, fibras de tempos entremeadas. Ou seja, a operação de Didi-Huberman é a de transformar aquilo que outrora era o 'pecado maior' do historiador - o anacronismo - em essência do ofício. Assim, anacronismo nunca poderia ser totalmente eliminado. No entanto, Sarlo contrapõe:

Reconhecer isso, porém, não implica que todo relato do passado se entregue a essa heterogeneidade como a um destino fatal, mas que trabalhe com ela para alcançar uma reconstrução 
inteligível, ou seja: que saiba com que fibras está construída e, como se se tratasse da trama de um tecido, que as disponha para mostrar da melhor maneira o desenho pretendido. ${ }^{21}$

Por fim, cabe dizer que o balanço realizado por Beatriz Sarlo tem importância fundamental uma vez que fornece uma série de questões a serem colocadas antes de uma partida irrestrita ao campo da memória que, atualmente, parece oferecer um oásis ao ofício do historiador. Isso porque, permanece o seguinte paradoxo: ainda que por séculos, a história e a literatura tratassem de prover seus leitores de narrativas portadoras de experiências das mais diversas - do trágico ao cômico, do monstruoso ao sublime - o historiador parece, contemporaneamente, em dúvida em relação a sua capacidade para tal empresa, mesmo que, de maneira irrestrita, a fotografia e o cinema continuem a ampliar e a massificar este repertório que já alimentava, em boa medida, as possibilidades do viver na cultura ocidental.

\section{NOTAS}

I WINTER, J. "A geração da memória: reflexões sobre o 'boom da memória' nos estudos contemporâneos de história". In: SELIGMANN-SILVA, M (org.). Palavra e imagem: memória e escritura. Chapecó: Argos, 2006. p. 68.

2 SCHMIDT, B. B. "Entre a filosofia e a sociologia: matrizes teóricas as discussões atuais sobre história e memória”. In: Estudos Íbero-Americanos. PUCRS, v. XXXII, n. I, p. 85-97. junho de 2006. p. 86.

3 SARLO, B. Tempo passado: cultura da memória e guinada subjetiva. São Paulo: Companhia das Letras; Belo Horizonte: UFMG, 2007. p. 17.

4 Ibidem. p. 18.

5 Idem. p. II.

6 MAIER, Charles apud SARLO, B. Idem. p. II.

7 SARLO, B. Op. Cit. p. 44.

8 Ibidem. p. 43.

9 CALVEIRO, P. Poder y desaparición: Los campos de concentración em Argentina. Buenos Aires: Colihue, 1998.

IO BENJAMIN, W. "O narrador. Considerações sobre a obra de Nikolai Leskov". In: Magia e técnica, arte e política: ensaios sobre literatura e história da cultura. São Paulo: Brasiliense, 1994. p. 197-221 . p. 195

I I SARLO, B. Op. Cit. p. 25.

12 Ibidem. p. 26.

13 GINZBURG, C. "Prueba, memoria y olvido". In: Nuestra memoria. Ano XI, n. 26. Buenos Aires, 2005. www.fmh.org.ar/revista/26/nuestra\%memoria\%2026.pdf

I 4 SARLO, B. Op. Cit. p. 27.

I 5 Ibidem. p. 27.

16 Idem. p. 28.

17 Idem. p. 48.

18 Idem. p. 56.

19 Idem. p. 57-58.

20 DIDI-HUBERMAN, Georges. Ante el tiempo: historia del arte y anacronismo de las imágenes. Buenos Aires: Adriana Hidalgo Editora, 2006.

2I SARLO, Beatriz. Op. Cit. p. 60. 